\title{
PENGARUH MOTIVASI KERJA DAN KOMITMEN ORGANISASI TERHADAP ORGANIZATIONAL CITIZENSHIP BEHAVIOR (OCB) KARYAWAN CU BETANG ASI KANTOR PUSAT PALANGKA RAYA
}

\author{
Vida Aknes Monika ${ }^{1 *}$ Yohanes Kalvin Anggen $^{2}$ Luluk Tri Harinie $^{3}$ \\ Fakultas Ekonomi dan Bisnis \\ Universitas Palangka Raya \\ e-mail: vidaaknesmonika98@gmail.com
}

\begin{abstract}
Abstrak
Tujuan - Penelitian ini bertujuan untuk mengetahui berapa besar pengaruh Motivasi Kerja dan Komitmen Organisasi Terhadap Organizational Citizemship Behavior (OCB) Karyawan CU Betang Asi Kantor Pusat Palangka Raya.

Desain/Metodelogi/Pendekatan - Metode penelitian menggunakan pendekatan deskriptif kuantitatif dengan jumlah sampel 34 orang responden. Teknik analisis dalam penelitian ini meliputi analisis deskriptif dan Struktural Equation Model (SEM) dengan alat analisis Smart-PLS.

Hasil Penelitian - Hasil analisis Smart-PLS menunjukkan bahwa motivasi kerja berpengaruh positif dan signifikan terhadap organizational citizenship behavior, komitmen organisasi berpengaruh positif dan signifikan terhadap organizational citizenship behavior.
\end{abstract}

\section{Kata Kunci: Motivasi Kerja, Komitmen Organisasi, organizational citizenship behavior}

\section{The Efeect Of Work Motivation And Organizational Commitment On Organizational Citizenship Behavior (OCB) Employees Cu Betang Asi Head Office Palangka Raya}

\begin{abstract}
:
Purpose - This study aims to determine how much influence Work Motivation and Organizational Commitment have on Organizational Citizenship Behavior (OCB) of Betang Asi CU employees at Palangka Raya Head Office.

Design/Methodology/Approach - The research method uses a quantitative descriptive approach with a sample of 34 respondents. The analytical techniques in this study include descriptive analysis and Structural Equation Model (SEM) with the Smart-PLS analysis tool.

Finding - The results of the Smart-PLS analysis show that work motivation has a positive and significant effect on organizational citizenship behavior, organizational commitment has a positive and significant effect on organizational citizenship behavior.
\end{abstract}

Keywords: Work Motivation, Organizational Commitment, organizational citizenship behavior 


\section{PENDAHULUAN}

Seiring berlangsungnya globalisasi khususnya dalam bidang ekonomi menempatkan sektor keuangan. Sebagai salah satu sektor dalam perekonomian suatu Negara sektor keuangan berperan mengupayakan terpenuhinya kebutuhan dana untuk membiayai aktivitas ekonomi masyarakat maupun aktivitas pemerintah selaku penyelenggara Negara. Didalam masyarakat lembaga keuangan ini dibedakan lembaga keuangan bank dan non bank. Kedua lembaga ini berperan sebagai mediator mengumpulkan dana dari masyarakat dan menyalurkannya kepada para pelaku ekonomi yang membutuhkan dana untuk membiayai investasinya. Aktivitas pelaku lembaga keuangan ini dalam struktur ekonomi nasional kita disebut dengan sektor keuangan. Menyadari arti peran dan fungsi sektor keuangan menjadikan keberadaan lembaga keuangan dipandang menarik dan bermanfaat. Pada kesempatan ini Credit Union (CU) Betang Asi Kantor Pusat Palangka Raya sebagai salah satu pelaku sektor keuangan dengan status lembaga keuangan non bank dipilih jadi objek.

Dalam dunia yang kompetitif saat ini keberhasilan tercapainya tujuan suatu organisasi baik perusahaan swasta maupun milik Negara atau sektor publik sangat tergantung pada kemampuan dan keahlian pimpinan dalam melaksanakan fungsi organisasi seperti pemasaran, produksi, keuangan, administrasi dan personalia. Untuk mewujudkan hal tersebut diperlukan sumber daya manusia yang berkualitas agar dapat mencapai tujuan organisasi (Gina, 2013). Sumber daya manusia adalah harta atau asset yang paling berharga dan paling penting dimiliki oleh organisasi, karena keberhasilan organisasi sangat ditentukan oleh unsur manusia (Putra dan Sudibya, 2018).

Organisasi yang berhasil memerlukan sumber daya seperti disebut diatas dan juga harus mampu melakukan tugas melebihi tuntutan peran yang dibebankan kepadanya. Dalam melaksanakan tugas organisasi harus memiliki sumber daya manusia yang tidak hanya melakukan masing-masing tugasnya saja namun para karyawan juga perlu memiliki ekstra peran demi tercapainya tujuan organisasi (Satyawan dan Netra, 2017).

Memiliki karyawan yang bersedia mencurahkan segenap kemampuannya demi kepentingan organisasi adalah harapan bagi setiap organisasi. Salah satu perilaku Organizational Citizenship Behavior (OCB) atau perilaku kewarganegaraan organisasi yang berarti perilaku individu yang sukarela dan bukan bagian dari syarat formal pekerjaan, tetapi dapat meningkatkan stabilitas kinerja organisasi (Dramawan dan Mujiati, 2017). Tujuan yang diinginkan oleh organisasi adalah memiliki karyawan yang berperilaku OCB. OCB dapat timbul dari berbagai faktor dalam organisasi, diantaranya karena adanya Motivasi Kerja dari pimpinan dan Komitmen Organisasi yang tinggi (Robbin \& Judge, 2007).

Motivasi merupakan hal yang sangat penting yang harus diperhatikan oleh pihak manajemen apabila mereka menginginkan setiap karyawan dapat memberikan kontribusi positif terhadap pencapaian tujuan organisasi (Murty dan Hudiwinarsih, 2012). Dengan adanya motivasi, seorang karyawan akan memiliki semangat yang tinggi dalam melaksanakan tugas yang dibebankan kepadanya. Tanpa motivasi, seorang karyawan tidak dapat melakukan tugasnya sesuai dengan standar atau bahkan melampaui standar karena yang menjadi motivasinya dalam bekerja tidak terpenuhi (Budianto dkk., 2017).

Motivasi Kerja dapat diidefinisikan sebagai suatu kondisi untuk memberikan dorongan terhadap individu yang dapat menyebabkan individu tersebut berbuat dan berperilaku yang akan mengarah pada pencapaian tujuan organisasi (Soekanto Reksohadiprodjo dan T. Hani Handoko, 2007). Motivasi Kerja yang rendah atau kurang baik akan merugikan perusahaan, karena dengan motivasi kerja yang lemah pencapaian 
tujuan perusahaan tidak tercapai secara maksimal (Novia Musyaroh, 2018). Ketika individu telah memiliki Motivasi Kerja yang tinggi maka perilaku OCB secara otomatis mengalami peningkatan, individu tersebut akan lebih giat dalam melakukan pekerjaannya (Dewi dan Riana, 2019.

Selain Motivasi Kerja, yang dapat mempengaruhi OCB karyawan adalah Komitmen Organisasi. Yaitu tingkat keterlibatan karyawan dalam organisasinya dan berkeinginan untuk tetap menjadi anggota organisasi, dimana didalamnya mengandung sikap kesetiaan dan kesediaan karyawan untuk bekerja secara maksimal bagi organisasi tempat karyawan tersebut bekerja (Greenberg dan Baron, 2003). Hal tersebut dapat dipengaruhi oleh adanya karyawan yang memiliki komitmen tinggi yang akan berusaha semaksimal mungkin untuk mencapai tujuan dan bertanggung jawab atas segala pekerjaan yang dilakukan. Selain itu karyawan yang telah memiliki keterikatan emosional dengan rela dan ikhlas melakukan ekstra peran seperti misalnya membantu rekan kerja lain yang membutuhkan tanpa mengharapkan imbalan (Putra dan Sudibya, 2018).

Meningkatkan perilaku OCB dalam dunia kerja, tidak lepas dari bagaimana komitmen yang ada dalam diri individu tersebut. Individu yang memiliki komitmen tinggi, mereka akan lebih peduli dengan nasib organisasinya dan berusaha untuk mewujudkan tujuan organisasi (Kerisna dan Suana, 2017). Penelitian yang dilakukan oleh (Diatmika dan Suwandana, 2016) yang menyatakan bahwa semakin tinggi Komitmen Organisasi, maka semakin tinggi pula perilaku OCB.

Bagi sebagian masyarakat Kalimantan Tengah CU Betang Asi sudah cukup di kenal sebagai lembaga keuangan yang menghimpun dana dari masyarakat dan meminjamkannya kepada masyarakat. Nama CU kependekan dari "Credit Union" yang berasal dari kata Credere berarti kepercayaan dan Union atau Unus yang berarti kumpulan, lebih lanjut dimaknai "kumpulan orang yang saling percaya" dalam suatu ikatan pemersatu, sepakat menabungkan uang mereka membentuk modal bersama untuk di pinjamkan kepada anggota untuk tujuan produktif dalam upaya peningkatan kesejahtraan. Sejak diperkenalkan awal abad ke-19 CU adalah sebuah gerakan untuk melepaskan belenggu kemiskinan.

Berdasarkan kajian teori dan hasil penelitian terdahulu yang terkait dengan penelitian ini, untuk menentukan objek dan subjek penelitian yang tepat, penting sekali dilakukan studi pendahuluan. Studi pendahuluan dilakukan dengan menyebarkan kuesioner kepada 20 orang responden karyawan CU Betang Asi Kantor Pusat Palangka Raya, hasilnya diperoleh nilai skor rata-rata persepsi responden mengenai Motivasi Kerja sebesar 3,44 dengan kategori setuju, artinya responden setuju bahwa Motivasi Kerja adalah dorongan dan semangat yang muncul dari dalam diri maupun diluar diri individu untuk melakukan suatu tindakan guna mencapai tujuan tertentu dengan tingkat capaian $68,8 \%$. Untuk variabel Komitmen Organisasi diperoleh skor rata-rata persepsi responden sebesar 3,6 dengan kategori setuju, artinya responden setuju bahwa Komitmen Organisasi adalah suatu sikap yang mencerminkan loyalitas karyawan terhadap organisasi, melalui keterlibatan dan berkeinginan tetap bertahan dalam organisasi untuk mencapai tujuan organisasi dengan tingkat capaian $72 \%$. Sedangkan skor rata-rata persepsi responden untuk variabel OCB sebesar 3,2 dengan kategori setuju, artinya responden setuju bahwa OCB adalah perilaku sukarela menolong rekan kerja tanpa diperintah maupun diberi kompensasi atau penghargaan dengan tingkat capaian sebesar $64 \%$. Kemudian hasil uji secara parsial berpengaruh positif dan signifikan terhadap Variabel Y (Organizational Citizenship Behavior) karyawan CU Betang Asi Kantor Pusat Palangka Raya. 
Berdasarkan hasil studi pendahuluan diatas dapat diketahui masalah yang terjadi pada variabel Motivasi Kerja, Komitmen Organisasi dan OCB karyawan CU Betang Asi Kantor Pusat Palangka Raya, belum optimal capaiannya. Karena itu penelitian ini akan diberi judul "Pengaruh Motivasi Kerja dan Komitmen Organisasi terhadap Organizational Citizenship Behavior (OCB) karyawan CU Betang Asi Kantor Pusat Palangka Raya"

\section{KAJIAN PUSTAKA}

\section{Organizational Citizenship Behavior}

Organization citizenship behavior diartikan sebagai perilaku- perilaku dari para pekerja yang melebihi yang disyaratkan oleh peran formalnya serta tidak secara langsung dan eksplisit diakui oleh sistem kompensasi/reward yang resmi/formal, namun secara agregat mampu meningkatkan efektivitas fungsi organisasi (Organ 1988); OCB ini melibatkan beberapa perilaku meliputi perilaku suka menolong orang lain, menjadi volunteer untuk tugas-tugas ekstra, patuh terhadap aturan dan prosedur di tempat kerja. Perilaku ini menggambarkan "nilai tambah karyawan" dan merupakan salah satu bentuk prososial positif, konstruktif dan bermakna membantu (Aldag \& Resckhe, 1997). Pendapat senada dikemukan oleh (Greenberg dan Baron, 2000) bahwa OCB merupakan perilaku individual yang bebas memilih, tidak diarahkan secara eksplisit oleh sistem yang diakui secara formal, namun membuat organisasi menjadi lebih baik berdaya guna dan efisien.

\section{Motivasi Kerja}

Motivasi kerja sebagai suatu kondisi untuk memberikan dorongan terhadap individu yang dapat menyebabkan individu tersebut berbuat dan berperilaku yang akan mengarah pada pencapaian tujuan organisasi (Soekanto Reksohadiprodjo dan T. Hani Handoko 2007). Motivasi kerja sebagai hasrat di dalam diri seseorang yang menyebabkan orang tersebut melakukan tindakan bekerja melakukan sesuatu (Robert L. Mathis).

\section{Komitmen Organisasi}

Komitmen organisasi adalah keterlibatan karyawan dalam organisasinya dan berkinginan untuk tetap menjadi anggota, didalamnya perwujudtan dari sikap kesetiaan dan kesediaan karyawan untuk bekerja secara maksimal bagi organisasi tempat karyawan tersebut bekerja (Greenberg \& Baron,2003); Kedekatan emosi, identik dengan keterlibatan individu dengan organisasi serta keinginan untuk tetap menjadi anggota organisasi (Allen \& Meyer).

Pendapat lain juga mengemukakan definisi komitmen organisasi adalah kesetiaan seorang individu terhadap organisasi (Schermerhorn,2005); adanya kebanggaan sebagai anggota organisasi, pekerja tidak hanya sekedar bekerja, tetapi disertai keberpihakan pada organisasi, serta berniat untuk memelihara keanggotaanya dalam organisasi. Pemihakan seseorang kepada pekerjaannya, menunjukkan keterlibatan kerja yang tinggi. Komitmen yang tinggi pada organisasi menunjukkan adanya pemihakan (Robbins, 2005). 


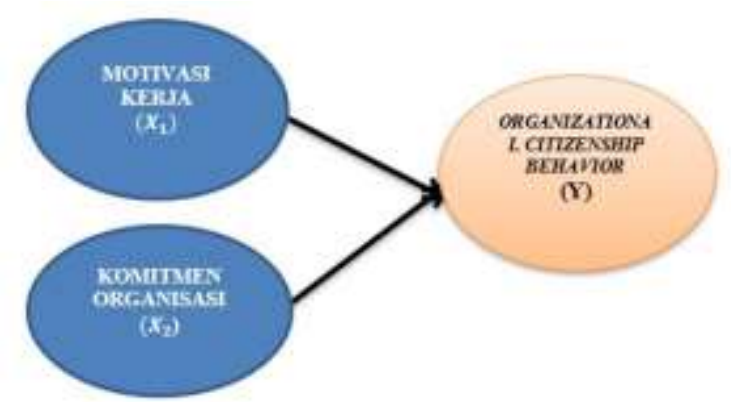

Gambar 1. Kerangka Pemikiran

$H_{1}=$ Diduga Motivasi Kerja berpengaruh terhadap Organizational Citizenship Behavior.

$\mathrm{H}_{2}=$ Diduga Komitmen Organisasi berpengaruh terhadap Organizational Citizenship Behavior.

\section{METODE PENELITIAN}

Jenis penelitian ini adalah penelitian ekplanasi, yaitu penelitian yang bermaksud menjelaskan kedudukan variabel-variabel yang diteliti serta pengaruh antara satu variabel dengan variabel lainnya (Menurut Sugiyono 2010). Pada penelitian ini pengaruh yang dimaksud adalah variabel bebas Motivasi Kerja, Komitmen Organisasi dan variabel terikat Organizational Citizenship Behavior (OCB). Dengan menggunakan pendekatan kuantitatif, pendekatan kuantitatif adalah pendekatan dalam penelitian yang menggunakan data berupa angka-angka untuk menganalisa hubungan antar variabel (Sugiyono, 2014).

Di dalam penelitian ini Populasi adalah seluruh karyawan CU Betang Asi Kantor Pusat Palangka Raya sejumlah 44 orang. Untuk memperoleh sampel dalam penelitian ini digunakan rumus Slovin (dalam Rachmat Kriyantono, 2010). Jadi jumlah sampel dalam penelitian ini 34 orang karyawan.

\section{HASIL DAN PEMBAHASAN}

\section{Analsis Deskriptif}

Deskripstif Variabel Motivasi Kerja $\left(X_{1}\right)$

Kesimpulan jawaban responden tentang variabel motivasi kerja $\left(X_{1}\right)$ menunjukkan skor rata-rata sebesar 3,66 dengan kategori setuju, artinya responden setuju bahwa motivasi kerja adalah dorongan dan semangat yang muncul dari dalam diri maupun diluar diri individu untuk melakukan tindakan guna mencapai tujuan tertentu dengan tingkat capaian $73,2 \%$.

Deskriptif Variabel Komitmen Organisasi $\left(X_{2}\right)$

Kesimpulan jawaban responden tentang variabel komitmen organisasi $\left(X_{2}\right)$ menunjukkan skor rata-rata sebesar 3,6 dengan kategori setuju, artinya responden setuju bahwa komitmen organisasi adalah suatu sikap yang mencerminkan loyalitas karyawan terhadap organisasi, melalui keterlibatan dan berkeinginan tetap bertahan dalam organisasi untuk mencapai tujuan organisasi dengan tingkat capaian $72 \%$.

Deskriptif Variabel Organizational Citizenship Behavior (Y)

Kesimpulan jawaban responden tentang variabel organizational citizenship behavior menunjukkan skor rata-rata sebesar 3.42 dengan kategori setuju, artinya responden setuju bahwa organizational citizenship behavior adalah perilaku sukarela menolong rekan kerja tanpa diperintah maupun diberikan kompensasi atau penghargaan dengan tingkat capaian $68,4 \%$. 


\section{Analisis Inferensial}

\section{Pengujiaan Convergent Validity}

Menguji Convergent Validity digunakan nilai Outer loading atau outer factor. Suatu indikator dinyatakan memenuhi syarat convergent validity dalam kategori apabila nilai outer loading $>0,7$.

\section{Tabel 1 Convergent Validity}

\begin{tabular}{cccc}
\hline \multirow{2}{*}{ Motivasi Kerja } & X1.1 & 0.849 & Valid \\
\cline { 2 - 4 } & $\mathrm{X} 1.2$ & 0.866 & Valid \\
\cline { 2 - 4 } & $\mathrm{X} 1.3$ & 0.906 & Valid \\
\cline { 2 - 4 } & $\mathrm{X} 1.4$ & 0.871 & Valid \\
\cline { 2 - 4 } Komitmen Organisasi & $\mathrm{X} 1.5$ & 0.891 & Valid \\
\hline & $\mathrm{X} 2.1$ & 0.971 & Valid \\
\cline { 2 - 4 } Organizational Citizenship Behavior & $\mathrm{X} 2.2$ & 0.954 & Valid \\
\cline { 2 - 4 } & $\mathrm{Y} 2.3$ & 0.954 & Valid \\
\cline { 2 - 4 } & $\mathrm{Y} 1.2$ & 0.938 & Valid \\
\cline { 2 - 4 } & $\mathrm{Y} 1.3$ & 0.969 & Valid \\
\cline { 2 - 4 } & $\mathrm{Y} 1.4$ & 0.945 & Valid \\
\cline { 2 - 4 } & $\mathrm{Y} 1.5$ & 0.904 & Valid \\
\hline
\end{tabular}

Sumber: Konsep Outer Model SmartPLS 3.3.3 (2021)

Hasil pengujian diatas pada Tabel 1 menunjukkan bahwa seluruh outer loading indikator konstruk memiliki nilai diatas 0.7 . Jadi dapat disimpulkan bahwa pengukuran ini mrmrnuhi persyaratan validitas konvergen.

\section{Composite Reliability}

Tabel 2. Hasil Pengujian Composite Reliability

\begin{tabular}{cccccc}
\hline Variabel & $\begin{array}{c}\text { Composite } \\
\text { Reliability }\end{array}$ & Nilai & Conbach's Alpha & Nilai & $\begin{array}{c}\text { Evaluasi } \\
\text { Model }\end{array}$ \\
\hline Motivasi Kerja & 0.972 & & 0.968 & & \\
\hline $\begin{array}{c}\text { Komitmen } \\
\text { Organisasi }\end{array}$ & 0.944 & $>0.7$ & 0.926 & $>0.7$ & Reliabel \\
\hline $\begin{array}{c}\text { Organizational } \\
\text { Citizenship Behavior }\end{array}$ & 0.97 & & 0.967 & & \\
\hline Sumb Lampian & & & & \\
\hline
\end{tabular}

Sumber: Lampiran

Berdasarkan Tabel 2 diatas hasil pengujian Composite Reliability menunjukkan nilai yang memuaskan, yaitu semua variabel laten reliabel memiliki nilai Composite Reliability > 0,7. Haln ini bahwa kuesioner yang digunakan sebagai alat dalam penelitian ini telah andal atau konsisten. 


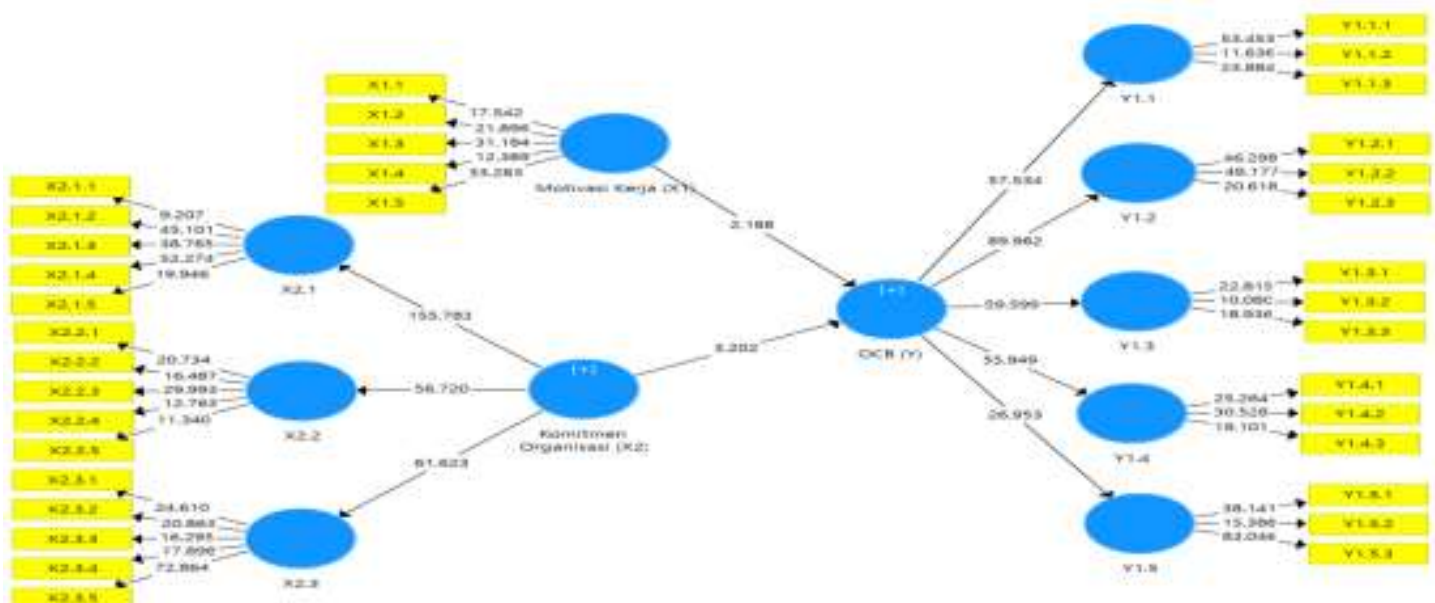

Gambar 2. Permodelan persamaan struktural pendekatan PLS

Tabel 3. Nilai predictive-relevance $\left(Q^{2}\right)$.

\begin{tabular}{l|r|r|r|} 
& SSO & SSE & $Q^{2}(=1-$ SSE/SSO) \\
\hline KOMITMEN ORGANISASI (X2) & 510.000 & 510.000 & \\
\hline MOTIVASI KERJA $(X 1)$ & 170.000 & 170.000 & \\
\hline OCB $(Y)$ & 510.000 & 221.650 & 0.565
\end{tabular}

Sumber: Lampiran

Hasil perhitungan diatas memperlihatkan nilai predictive-relevance sebesar $0.565>0$. Hal ini berarti bahwa 56,5\% variasi pada variabel OCB dijelaskan oleh variabel-variabel yang digunakan. Dengan demikian model dikatakan layak memiliki nilai prediktif yang relevan.

\section{Hasil Pengujian Hipotesi}

Tabel 3 Hasil Pengujian Hipotesi

\begin{tabular}{cccccc}
\hline & $\begin{array}{c}\text { Original } \\
\text { Sample } \\
\text { Estimate }\end{array}$ & $\begin{array}{c}\text { Sample } \\
\text { Mean }\end{array}$ & STDEV & T-statistic & P-values \\
\hline $\begin{array}{c}\text { Komitmen Organisasi } \\
(\mathrm{X} 2) \rightarrow \text { OCB (Y) }\end{array}$ & 0.616 & 0.603 & 0.192 & 3.202 & 0.001 \\
\hline $\begin{array}{c}\text { Motivasi Kerja (X1) } \rightarrow \\
\text { OCB (Y) }\end{array}$ & 0.423 & 0.434 & 0.193 & 2.188 & 0.028 \\
\hline
\end{tabular}

Sumber: Konsep Path Coefficient (Mean. STIDEV, T-statistic, P-values) lampiran

Terdapat pengaruh positif dan signifikan antara motivasi kerja terhadap organizational citizenship behavior (OCB)

Hasil pengujian dapat dilihat bahwa motivasi kerja berpengaruh positif dan signifikan terhadap OCB yang ditunjukkan dengan nilai t-statistik 2.188 lebih besar dari nilai t-tabel 1,96 serta p-values 0.029 lebih kecil dari 0,05. Artinya, semakin meningkat motivasi kerja maka semakin meningkat juga perilaku OCB karyawan. 
Terdapat pengaruh positif dan signifikan antara komitmen organisasi terhadap organizational citizenship behavior (OCB)

Hasil pengujian dapat dilihat bahwa komitmen organisasi berpengaruh positif dan signifikan terghadap OCB yang ditunjukkan oleh nilai t-statistic 3.202 lebih besar dari nilai t-tabel 1.96 serta p-values 0.001 lebih kecil dari 0,05. Artinya, semakin meningkat komitmen organisasi maka semakin meningkat juga perilaku OCB karyawan.

\section{KESIMPULAN}

Hasil analisis deskriptif menunjukkan bahwa variabel motivasi kerja $\left(X_{1}\right)$ mempunyai skor rata-rata jawaban responden sebesar 3,66 dengan kategori setuju, artinya responden setuju bahwa motivasi kerja adalah dorongan dan semangat yang muncul dari dalam diri maupun diluar diri individu untuk melakukan suatu tindakan guna mencapai tujuan tertentu dengan tingkat capaian $73,2 \%$, dan berdasarkan hasil uji path coefficient antara variabel motivasi kerja $\left(X_{1}\right)$ terhadap OCB $(Y)$ menunjukkan t-statistic $2.188>\mathrm{t}$ tabel 1,96 dan signifikansi $0,029<0,05$ maka dapat disimpulkan bahwa $H_{0}$ ditolak dan $H_{1}$ diterima. Artinya variabel motivasi kerja $\left(X_{1}\right)$ berpengaruh positif dan signifikan terhadap OCB (Y).

Hasil analisis deskriptif menunjukkan bahwa variabel komitmen organisasi $\left(X_{2}\right)$ mempunyai skor rata-rata jawaban responden sebesar 3,6 dengan kategori setuju, artinya responden setuju bahwa komitmen organisasi adalah suatu sikap yang mencerminkan loyalitas karyawan terhadap organisasi, melalui keterlibatan dan berkeinginan tetap bertahan di organisasi untuk mencapai tujuan organisasi deangan tingkat capaian $72 \%$, dan berdasarkan uji path coefficient antara variabel komitmen organisasi $\left(X_{2}\right)$ terhadap OCB (Y) menunjukkan t-statistic $3.202>$ t-tabel 1,96 dan signifikansi $0,001<0,05$ maka dapat disimpulkan bahwa $H_{0}$ ditolak dan $H_{2}$ diterima. Artinya variabel komitmen organisasi $\left(X_{2}\right)$ berpengaruh positif dan signifikan terhadap OCB (Y).

\section{REFERENSI}

Armstrong, M. (1991). Personal Management Practice. London.

Budianto, Agung, Yonathan Pongtuluran dan Syaharuddin Y. (2017). Pengaruh ertika kerja, motivasi kerja dan kompensasi finansial terhadap kinerja karyawan. Journal FEB Unmil, 14(1), 1-5.

Besra, Eri. (2019). Analsis Keterkaitan Stroke Image, Customer Satisfaction dan Repurchase Intentuion (Survei Pada Pelanggan SJS PLAZA).

Bukit, Benjamin, Tasman Malusa dan Abdul Rahmat. (2017). Pengembangan Sumber Daya Manusia.Yogyakarta: Zahir Publishing.

Danendra, A A Ngurah Bagus dan Ni Wayan Mujiati. (2016). Pengaruh Motivasi, Kompensasi dan Komitmen Organisasional Terhadap Organizational Citizhensip Behavior (OCB). E-Jurnal Manajemen Unad, 5 (10), 6229-6259.

Darto, Mariman. Peran Organizational Citizenship Bhavior (OCB) Dalam Peningkatan Kinerja Individu Di Sektor Publik: Sebuah analisis Teoritis dan Empiris.

Dewi, Kadek Diah Candra dan Gede Riana. (2019). Pengaruh Motivasi Kerja, Komitmen Organisasional dan Kepuasan Kerja Terhadap Organizational Citizhensip Behavior (OCB) PNS pada Seketariat DPRD Kabupaten Bandung. Jurnal Ilmu Manajemen dan 
Bisnis, 203-214.

Diatmika, I Nyoman Crana Yuliana dan I Gusti Made Suwandana. (2016). Pengaruh Komitmen Organisasi dan Motivasi Kerja Terhadap Organizational Citizenship Behavior Alam Puri. E-Jurnal Unud, 5 (11), 7128-7155.

Dramawan, I Ketut Merta dan Ni Wayan Mujiati. (2016). Pengaruh Kepemimpinan Tranformasional dan Komitmen Organisasiobal Terhadap Organizational Citizenship Behaviordi Kantor Inspektorat Bandung. E-Jurnal Manajemen Unud, 6 (12), 68806912.

Edy, Sutrisno. (2011). Manajemen Sumber Daya Manusia. Jakarta: Kencana.

Ferdinand, A (2014). Metode Penelitian Manajemen, Pedoman Penelitian untuk Penulisan Skripsi, Tesis dan Disertasi. Semarang: Badan Penerbit Universitas Diponegoro.

Fred, Luthans. (2005). Perilaku Organisasi. Edisi Sepuluh. Yogyakarta: Penerbit Andi

Fred, Luthans. (2006). Perilaku Organisasi. Edisi Sepuluh. Yogyakarta: PT.Andi.

Ghozali, Imam. (2015). Aplikasi Ananlisis Multivariate dengan Program IMB SPSS 23. Semarang: Badan Penerbit Universitas Diponegoro.

Gina, Tampi Sheelsia. (2013). Kepemimpinan dan Kompensasi Pengaruhnya Terhadap kinerja Karyawan dan Dampaknya Terhadap Organizational Citizenship Behavior (OCB). Jurnal EMBA, 1 (3), 921-929.

Hariandja, Merihot Tua Effendi. (2007). Sumber Daya Manusia. Edisi Keempat. Jakarta: Gransindo.

Hasibuan, Malayu S.P. (2006). Manajemen Dasar, Pengertian dan Masalah, Edisi Revisi, Jakarta: Bumi Aksara

Hasibuan, Malayu SP. (2013). Manajemen Sumber Daya Manusia. Jakarta: PT. Bumi Aksara.

Heidjrachman, Ranupandojo, dan Saud Husnan, (2000). Manajemen Personalia. Edisi Keempat. Yogyakarta: BPFE UGN.

Husein, Umar. (2011). Metode Penelitian Untuk Skripsi dan tesis Bisnis Edisi 11. Jakarta: PT Raja Grafindo Persada.

Kerisna, I Gede Made Adhi dan I Wayan Suana. (2017). Pengaruh Kepuasan Kerja Terhadap Komitmen Organisasional dan Organizational Citizenship Behavior (OCB). E-Jurnal Manajemen Unud, 6 (7), 3962-3990.

Juniarari. (2011). Komitmen Organisasi. Jakarta.

Kriyantono, Rachmat. (2010). Teknik Praktis Riset Komunikasi: disertai contoh riset. Jakarta: Kencana.

Mardanadi, Syadza Aniga. (2018). Analisis Loyalitas Karyawan, Kepuasan Kerja dan Happiness Work Terhadap Organizational Citizenship behavior Pada Generasi Millenial Di Jabodetabek.

Marliani, Rosleny. (2015). Psikologi Industri dan Organisasi. Bandung : CV Pustaka Setia. Murty, Windy Aprilia dan Gunasti Hudiwinarsih. (2012). Pengaruh Kompensasi, Motivasi 
Dan Komitmen Organisasional Terhadap Kinerja Karyawan Bagian Akuntansi (Studi Kasus Oada Perusahaan Manufaktur Di Surabaya). The Indonesian Accounting Review. 2 (2), 215-228.

Mustafa, dan Wijaya T. (2012). Panduan Teknik Statistik SEM \& PLS dengan SPSS AMOS. Cahaya Atma Pustaka, Yogyakarta.

Muyasyaroh, Novia. (2018). Pengaruh Komitmen Organisasi dan Mativasi Kerja Terhadap Organizational Citizenship Behavior (OCB) Pada Karyawan Divisi Antaran PT. Pos Indonesia Cabang Jamber.

Oktora, Saraswati. (2017). Faktor-Faktor yang mempengaruhi Komitmen Organisasian Karyawan PT Dana Pensiun Telkom.

Pradiansyah, Arvan. (1999). Lima Prinsip Pembangun Komitmen. Jakarta: Pustaka Binaman Pressindo.

Priyono dan Marnis. (2014). Manajemen Sumber Daya Manusia. Sidoarjo: Zifatama Publisher.

Putra, I Putu Adi Kusuma dan I Gede Adyana Sudibya. (2018). Pengaruh Kepuasan Kerja, komitmen Organisasional dan Motivasi Kerja Terhadap Organizational citizenship Behavior. E-Jurnal Manajemen Unud, 7(8), 4447-4474.

Reksohadiprodjo, Sukanto dan T. hani Handoko. (2007). Organisasi Perusahaan. Edisi Kedua, Yogyakarta: BPFE

Rifqi, Luzman. (2019). Pengaruh Motivasi Kerja Terhadap Organizational Citizenship Behavior Dengan Komitmen Organisasional Sebagai Variabel Moderasi. (Studi Kasus Pada Bank Syariah Mandiri KCP Ungaran).

Rini, Gita Setya dan Mudji Rahardjo. (2014). Analisis Pengaruh Komitmen Organisasional Terhadap Organizational Citizenship behavior (Studi Karyawan Bank Indonesia Kantor Perwakilan Purwokerto). Ejurnal-s 1.undip.ac.id/index.php/dbr.

Ristiana, Merry. (2013). Pengaruh Komitmen Organisasi Dan Kepuasan Kerja Terhadap Organizational Citizenship Behavior (OCB) Dan Kinerja Karyawan Rumah Sakit Bhayangkara Trijata Denpasar DIE, Jurnal Ilmu Ekonomi \& Manajemen Januari

Robbin, SP. (2003). Perilaku Organisasi. Jilid I. Tim Indeks Jakarta: PT Indeks Kelompok Gramedia.

Robbins, SP dan Judge. (2008). Perilaku Organisasi Buku 2. Jakarta: Salemba Empat

Robbins, SP, Judge. (2007). Perilaku Organisasi, Alih Bahasa Drs. Benjamin Molan. Jakarta: Salemba Empat.

Robbins, SP. (2008). Organizational Behaviour, Tenth Edition (Perilaku Organisasi Edisi ke Sepuluh). Alih Bahasa Drs.Benyamin Molan. Jakarta: Salemba Empat.

Sambung, Roby. (2016). Dimensi Komitmen Organizational: Dampaknya Terhadap Terhadap Perilaku Kerja Pada Organisasi Sektor Publik. Jurnal Terapan Manajemen dan Bisnis, 28-37

Satyawan, I Putu Adi dan I Gusti Salit Ketut Netra. (2017). Pengaruh Kepemimpinan Transformasional, Kepuasan Kerja dan Komitmen Organisasi Terhadap 
Organizational Citizenship Behavior. E-Jurnal Manajemen Unud, 6 (7), 3651-3682.

Senjanti, Sendang. (2018). Hirarki Kebutuhan Menurut Abraham H.Maslow dan Relevansinya dengan Kebutuhan Anak Usia Dini Dalam Pendidikan.

Sengkey, Yuliana M, dkk. Pengaruh Kepuasan Kerja dan Komitmen Organisasi Terhadap Organizational Citizenship Behavior (OCB) Pegawai Pada Kantor Sekertariat Daerah Kabupaten Minahasa Tenggara.

Solimun, Achmad Adji. R.F, Nurjanah. (2017). Metode Statistik Multivariat Permodelan Persamaan Struktural (SEM) Pendekatan WarpPLS. Malang: UB Press.

Sugiyono. (2013). Metode Penelitian Pendekatan Pendidikan Kuantitatif, Kualitatif dan $R \& D$. Bandung: Alfabeta

Sugiyono. (2014). Metode Penelitian Pendidikan Kuantitatif, Kualitatif dan R\&D. Bandung: Alfabeta.

Sugiyono. (2016). Metode Penelitian Kuantitatif, Kualitatif dan R\&D. Bandung: Alfabeta.

Sugiyono. (2010). Metode Penelitian Kuantitatif, Kualitatif dan R\&D. Bandung: Alfabeta.

Sugiyono. (2019). Metode Penelitian Kuantitatif \& RDN. Bandung: Penerbit Alfabeta.

Tahir, Arifin. (2014). Perilaku Organisasi. Ed.1, Cet.1. Yogyakarta: CV Budi Utama.

Titisari, Purnamie. (2014). Peranan Organizational Citizenship Behavior (OCB) Dalam Meningkatkan Kinerja Karyawan.

Veithzal, Rivai. (2009). Manajemen Sumber Daya Manusia Untuk Perusahaan. Dari teori Ke Praktek. Jakarta: Rajawali Pers.

Wijaya, I. B. (2018). Pengaruh Komitmen Organisasi Dan Motivasi Terhadap Organizational Citizenship Behavior Perawat Rsud Panembahan Senopati Bantul. Jurnal Manajemen Bisnis Indonesia (Jambi), 7(2), 147-158.

Wijomo, Sutarto. (2010). Psikologi Industri dan organisasi: Dalam Suatu Bidang Gerak Psikologi Sumber daya Manusia. Edisi Revisi. Jakarta: Kencana.

Wiyono, FX Isbagyo. (1999). Menyamakan Persepsi tentang Komitmen. Jakarta: Binaman Pressindo.

Yulianue, Anue dan Andi Hendrawan. (2019). Organizational Citizenship behavior (OCB) dan Kelelahan Kerja Pada Nelayan.

(https://jodenmot.wordpress.com/2013/01/12/motivasi-teori-erg/2

https://www.kajianpustaka.com/2017/12/dimensi-motif-dan-manfaat-organizationalcitizenship-behavior.html? $\mathrm{m}=1$

https://www.dosenpendidikan.co.id/komitmen-organisasi/ 